\title{
Fishing Livelihoods and Social Diversity
}

\begin{abstract}
This chapter shifts scale from Chap. 2 to focus on the local context and analyse the everyday sets of social relationships that frame the lives of those engaged in fishing livelihoods. The broad structural forces of migration, technology and markets along with the wider economy all intersect with local sets of social structures to shape the conditions in which fishing livelihoods operate. Here we present two examples of how different forms of social differentiation interact with fishing livelihoods. In the Western Philippines, class and status intersect with cultural values to generate power relations and hierarchies in different roles associated with fishing livelihoods. In Pacific Island countries, gender norms structure the different types of fishing activities in which men and women are involved.
\end{abstract}

Keywords Class $\bullet$ Status $\bullet$ Gender $\bullet$ Philippines $\bullet$ Oceania $\bullet$ Value chain

This chapter shifts scale from Chap. 2 to focus on the local context and analyse the everyday sets of social relationships that frame the lives of those engaged in fishing livelihoods. The broad structural forces of migration, technology and markets along with the wider economy all intersect with local sets of social structures to shape the conditions in which fishing livelihoods operate. Understanding how these forms of social relationshipssuch as class, gender and ethnicity-operate in relation to fishing https://doi.org/10.1007/978-3-030-79591-7_3 
livelihoods matters, because it shows how both fishing livelihoods and governance projects to manage these livelihoods are socially differentiated.

Much policy-oriented literature and practice in fisheries takes as relatively unproblematic starting points the ideas of a 'community' and a 'fisher'. Yet, an individual is far more than a 'fisher' whose sole priority is to catch fish, and the idea of a 'fishing community' disguises a range of social cleavages, hierarchies and identities within groups. Different people will have different levels of engagement in fishing, different types of roles within fishing, and different expectations and understandings about fishing - all of which affect how we understand what their particular version of a fishing livelihood is, and how governors seek to manage it. For example, dominant narratives about fishers and poverty in developing countries (e.g., 'fishers are poor because they fish'; Béné, 2003) can lead to governance interventions that ignore the wider context of vulnerability in which fishers may live and that they prioritise (e.g., lack of access to health care, lack of land tenure or inequalities among different social groups) (Béné \& Friend, 2011; Fabinyi et al., 2015; Mills et al., 2011). Without careful attention to social differentiation, new governance institutions for sustainability are liable to get 'sucked up' into these existing patterns of inequality across class, gender, ethnic and other lines (Eder, 2005).

Many studies of social differentiation take the concept of class as their starting point. Early literature in political ecology, and much literature in discussions of agrarian change, uses the concept of class as a key marker of social differentiation, analysing the diverse ways in which groups of people engage with markets and relate to the means of production (e.g., as worker or owner). As Bernstein (2010: 22) summarises, such an approach is largely informed by asking basic questions on resource use, ownership and distribution. ${ }^{1}$

In the large-scale or industrial fisheries sector, there are significant class distinctions between boat owners and crew, reflected in systems of profit sharing (McCall Howard, 2012). However, in many small-scale fisheries, distinctions between owners and crew are frequently much less distinct and can be thought of instead as a form of 'petty commodity production', where owners occupy dual roles of both capital and labour (Russell \& Poopetch, 1990). Owners often work on their own vessels, employ crew through kin networks and have more egalitarian profit-sharing systems. In

\footnotetext{
' Specifically, 'Who owns what? Who does what? Who gets what? What do they do with it?'
} 
many other types of small-scale fisheries, there is no paid crew at all (i.e., it may just be a fisher, or a fisher with a family member), and the catch may be only partially marketed or used entirely for consumption. There are also often sharp class distinctions along the value chain, from producer to trader to consumer.

Beyond hierarchical categorisations of class, income and wealth, there are other distinctions between different types of fishers. For example, younger fishers, who in some cases are undertaking illegal fishing practices (Fabinyi, 2012; Lowe, 2002), may have different sets of economic goals compared to older fishers. Full-time fishers who rely on fishing as a sole source of income have different perceptions about fishing compared to part-time or seasonal fishers. The extraordinary diversity of gears and techniques mentioned in Chap. 2 means that new forms of governance, such as MPAs, have highly differentiated effects for different types of fishers (Eder, 2005).

Yet, livelihood roles are not the only factors underlying social differentiation (Hornborg et al., 2013). ${ }^{2}$ As political ecologists shifted from a primary focus on the forces of capitalism, they engaged with other ways of categorising social differentiation, including gender (Rocheleau et al., 1996), culture and ethnicity (Peet \& Watts, 1996). In line with developments in social anthropology, this approach foregrounded the roles of meaning, identity and interpretation over a 'materialist' emphasis on 'protein and profit' (Geertz, 1973; Sahlins, 1978). Individuals have multiple identities that can shift over time and according to circumstance, or can intersect. Importantly, forms of social differentiation are not necessarily 'natural', but have elements of social construction and can be used in strategic ways (Dressler \& Turner, 2008; Li, 2000). Ultimately, these markers of difference serve as crucial determinants of access to or exclusion from resources at the local level (Hall et al., 2011; Ribot \& Peluso, 2003).

In many cases forms of social differentiation can map on to dominant or subordinate roles within fishing livelihoods or fisheries value chains. For example, women tend to be more closely associated with near-shore fishing and gleaning as well as onshore roles such as processing and trading (Weeratunge et al., 2010). In South-East Asia, the ethnic Sama-Bajau tend to follow small-scale fishing livelihoods (Stacey et al., 2018), while in

${ }^{2}$ As Hornborg et al. (2013: 2) note, 'an attribution of decisive significance to material parameters in reproducing power structures should not imply down-playing the role of socio-cultural categories in organizing such structures'. 
South Asia different castes are associated with particular occupations, including fishing (Coulthard, 2008).

Here we present two examples of how different forms of social differentiation interact with fishing livelihoods. In the Western Philippines, class and status intersect with cultural values to generate power relations and hierarchies in different roles associated with fishing livelihoods. In Pacific Island countries, gender norms structure the different types of fishing activities in which men and women are involved.

\section{Class and Status in Western Philippines Fishing Communities}

Much social science of the political and economic development of the Philippines has highlighted relations of power and hierarchy (Kerkvliet, 1990; Sidel, 1999). In particular, inland agrarian regions, such as the sugar industry of Negros Island, or the rice-growing regions of Central Luzon, were characterised by sharp distinctions in assets and income between landowners and tenants, subsequently serving as the site of ongoing struggles over land reform. Compared to these agrarian regions, it can be more complex to characterise the forms of social differentiation in coastal communities (Eder, 2008). Yet, here too, economic roles and social identities interact to produce social institutions that condition forms of access and exclusion.

The classic division between the owner of the means of production and the wage labourer is reflected in various ways in coastal communities in the Western Philippines. In large-scale fishing vessels, owners of the vessels are typically located in urban spaces (e.g., municipal towns, provincial capital cities), and in many cases are owned by firms that may own several vessels. In these large-scale fisheries (e.g., lift nets, baby purse seines, trawlers) the distinction between boat owners and boat crew is, therefore, quite distinct, with the owners hiring the captain and crew. However, in rural areas of the Western Philippines where many small-scale fishers operate, divisions between people based on their relationship to the means of production can be less obvious. In coastal communities there are typically many diverse modes of fishing, using different gears to target different marine resources at different locations, at different times of the day, month and year, and individuals typically move across several fisheries at any one time. 
Many individuals or households straddle the distinctions between labour and capital as 'petty commodity producers'. For example, a fisher may own a motorised boat and work on it independently while employing other people as crew. In these circumstances, crews are often recruited through kin and/or neighbour networks, and the distribution of profits is frequently through a share system. In this system of profit sharing, shares may be allocated for the owner of the vessel and/or gear, and then distributed to crew members based on either total or individual catch. Some of the common types of small-scale fisheries operating in municipal waters are based on small, motorised boats with around two-four crew, which use gillnets to catch small pelagic fish or seagrass-dwelling species such as rabbitfish (Siganidae), or use hook and line to target live reef fish (see Fig. 3.1). Some vessels operate a hybrid system between the small-scale, petty commodity mode of production and that used by industrial ventures. For example, vessels fishing for fusiliers, sardines or mixed reef fish may have more than $20 \mathrm{crew}$ and go out for two or more weeks at a time, but the owner works on board as the captain and recruits crew through kin networks (Fabinyi, 2012).

Owners of motorised boats tend to be more visibly well-off than those who do not own a vessel. For those without capital in the form of a fishing vessel or gear, all of their fishing income must derive directly from how much they catch, and they tend to be among the poorest in any rural coastal community. Their housing is often made of temporary bush materials (nipa), and many have no access to electricity and go through periods of food insecurity (Fabinyi et al., 2017).

Frequently, the distinctions between boat owners and those without boats overlap with other forms of differentiation. Indigenous groups, such as the Mangyan in Mindoro and Tagbanua in Northern Palawan, tend to live inland or to participate in fisheries as hired crew (Dressler \& Fabinyi, 2011). In particular, a key axis of differentiation in many coastal communities in the Western Philippines (as elsewhere in the country) relates to migrant status (Knudsen, 2012, 2016). More recent migrants tend to have limited assets and need to find work on boats through actively setting up social relationships with boat owners. More recent migrants tend to be more socially and economically marginalised than residents who migrated earlier and have established themselves.

Differences in wealth and income are observed not just at the point of production (fishing), but also along the fisheries value chain. Depending on the type of fish that is caught, fish can be consumed within the 


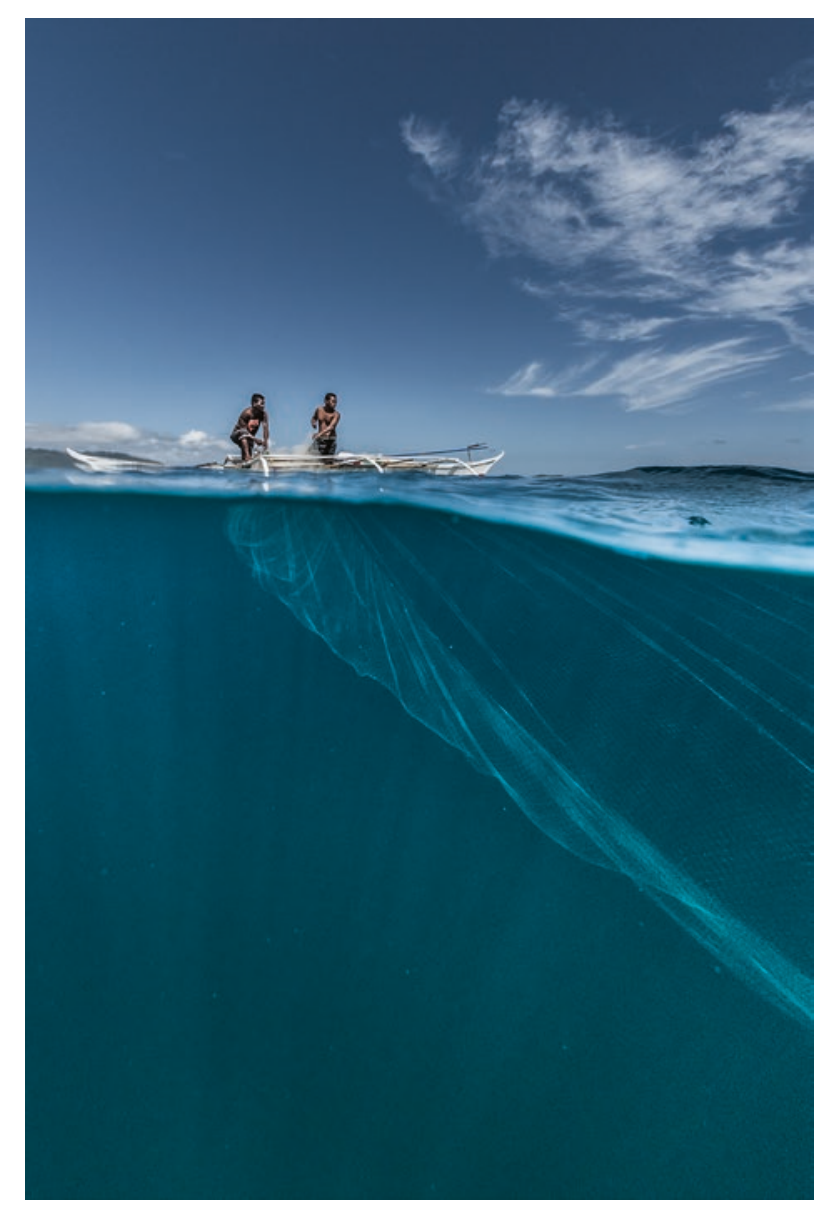

Fig. 3.1 Nets of fishers in Darocotan Bay, Philippines. (Photo credit: Katherine Jack)

household, bartered or given away, or sold at local urban, larger urban or international markets. A characteristic feature of many of these fish sales is that of the personalised economic relationship, which in essence involves a regular or favoured trading relationship (commonly referred to as suki). In theory, this offers mutual benefits for fishers and buyers: buyers are assured of regular supply, especially useful when supply is low, whereas fishers are 
assured of a regular buyer for their products (Ruddle, 2011). While local suki relationships are common, the intensity of the relationship can be increased when longer commodity chains and higher levels of capital are involved. In cases where fish are transported internationally (e.g., squid, live reef fish), buyers with greater resources finance fishing trips, the construction of boats with engines, and in some cases even the personal expenses (e.g., school fees, food) of fishers. Fishers are bound to sell their catch to the buyer who has financed them, and those who are financed receive lower prices than those who do not rely on a financier and are able to independently sell their fish.

The relationships between fishers and buyers in suki relationships are highly variable, but marked by power relations (Russell, 1987). This is particularly so when there are large differences in wealth between the two parties, and when a significant amount of credit is provided. In the case of export fisheries such as live fish and squid, for example, the local buyers who can afford to extend credit to fishers are either agents of exporters based in Manila, or local entrepreneurs with significant assets, and in many cases are politically well connected. In these cases, the relationship between the fisher and the trader closely resembles that of the patron and the client common in analyses of the Philippine political system, where the patron supplies the client with protection and security, and the client provides a loyal vote. Many traders higher up the value chain, such as the agents of exporters based in the provinces or the exporters themselves, have connections with ethnic Chinese, for example, through marriage.

Important in these contexts is the ability of fishers to actively work social relations to obtain relevant introductions to buyers and/or financiers. The personalised nature of the relationship is apparent in the common use of fictive kinship terms (e.g., kuya, older brother; tatay, father), and references to specific cultural values such as pakinabangan (reciprocity), apa (empathy) and hiya (shame) (Turgo, 2016). While patron-client relations in fisheries are sometimes criticised because some fishers become bound up in long-term debts (e.g., Padilla et al. 2003), fishers actively seek to turn these hierarchical relationships to their advantage. When negotiating the terms of such relationships, fishers will often appeal to strongly held moral values about the obligations of the well-off to take pity on the poor ( $a w a)$ and of the poor's 'right to survive' (Szanton, 1972). Fishers' claims in these ongoing relationships (e.g., financing the purchase of a boat, or gaining a position on a fishing vessel) are, therefore, situated within a broader cultural context (Fabinyi, 2012). Thus, fishers 
are economically differentiated in relation to the production process itself, and along the value chain, in ways that intersect with other forms of differentiation such as migrant status, and with broader cultural values.

The diversity of the roles associated with fisheries production and trade and the ways in which these roles link in with overlapping class and status relationships mean that a 'fishing livelihood' can only be understood in relation to its position within the local grid of social relationships. Therefore, as with all livelihoods, relations of power are a crucial—and frequently overlooked-component of livelihoods (De Haan \& Zoomers, 2005; Scoones, 2009). Often, these power relations are located beyond the geographically defined community in which a fisher lives: as Pauwelussen (2015: 332) notes in relation to Indonesian maritime peoples, 'affinity and loyalty follow translocal relations of kinship, credit, and debt rather than the borders of a village or island'.

These forms of differentiation and power relations are reflected not only in everyday operations of fishing livelihoods, but also become particularly visible through governance interventions. Where MPAs are located may have greater consequences for some groups of fishers and not others, and the decision-making processes by which these locations are finalised can reflect these power dynamics. For example, inshore fishers without motorised boats - and who tend to be poorer and with less political clout - have been disadvantaged in the site selection of MPAs (Eder, 2005; Fabinyi, 2012).

In the Philippines, the importance of power relations also comes into play in discussions of various types of illegal fishing. Illegal fishing is a contested term that can encompass a diverse set of fishing activities, from the use of 'active' gears in municipal waters such as beach seines, to the incursion of large-scale commercial fishing vessels in municipal waters, to the use of air compressors and of destructive gears such as cyanide and dynamite. Elsewhere in the coastal Philippines, Knudsen $(2012,2013)$ has shown that more recent migrants with lower status were subtly excluded from the benefits of marine conservation projects, and were more frequently blamed for illegal fishing incidents. In other parts of the coastal Philippines, blast fishers (Galvez et al., 1989) and commercial fishers illegally fishing within coastal waters (Segi, 2014a) have effectively integrated into the local community and are tolerated because of their power deriving from the significant economic benefits they distribute. In other cases, well-resourced illegal fishers are alleged to simply bribe government officials to allow them to operate (Fabinyi, 2012). In all these cases, formal 
governance of fishing livelihoods interacts with and is subsequently shaped by relationships of power and wealth on the ground.

\section{Gender in Fishing Livelihoods in Oceania}

All over the world the participation of women in fishing livelihoods is overlooked (e.g., see Ram, 1991). It is difficult to study women's roles in fisheries because data on fisheries are rarely disaggregated by sex of fisher (Harper et al., 2020). A systematic review of the literature on gender in fisheries found that in many parts of the world, including Africa and the Pacific Islands, women tend to fish close to shore, often gleaning for invertebrates, while men tend to fish further away from shore and catch more vertebrates (Kleiber et al., 2015). The paper found that people, including women, tend to see women's fishing as assisting men's fishing or as assisting with household incomes or food production, rather than as being important activities in their own right. For example, women in Kiribati looking after young children may take them swimming in shallow water, but also take a net and catch fish for dinner at the same time. When fishing is part-time or is for subsistence rather than for cash, it is often omitted from fisheries and census data collection. Moreover, gleaning as a method and invertebrates as catch are also often omitted from fisheries data collection (Gopal et al., 2020; Weeratunge et al., 2010). These factors combined render women's fishing invisible. For example, in the Pacific Island country of Wallis and Futuna a fisheries official told a visiting fisheries consultant that women do not fish in Wallis and Futuna. Later the consultant and the official had a lunch of shellfish together. When asked who collected the shellfish, the official answered that women did, but that this was not 'fishing' (Barclay et al., 2019: 3).

Fisheries researchers have found that in the countries of Oceania the proportion of women fishing for food and livelihoods ranges from around 20 per cent in some countries to around 50 per cent in others (Harper et al., 2013). One study in the Marovo Lagoon in Solomon Islands found that over 80 per cent of women fish or glean for invertebrates, and 84 per cent of women who fish target finfish rather than invertebrates (Rabbitt et al., 2019). Another study found that in Fiji women fishers play critical roles in food security and livelihoods (Thomas et al., 2020). However, the prevailing assumption that women do not fish is so pervasive that many women who fish do not see themselves as fishers, and data collection systems continue to omit the kinds of part-time, near-shore, 
invertebrate-focused fishing women most often do. For example, since around 2015 the Household Income and Expenditure Survey conducted in Pacific Island countries has asked women and men whether they fish for food and incomes. When the first-year data were collected only 8 per cent of women reported that they worked as fishers (Secretariat of the Pacific Community [SPC], 2017). Recognising that this figure was improbably low, the following year the Report Card noted 'women's participation in fisheries is underestimated by [the survey] ... with one country estimate being that no women are employed in fisheries (range $0 \%$ to $17 \%)^{\prime}(2018$ : $3)$. The figures were improved the year after that, with women being reported as making up 18 per cent of the fisheries workforce (range 8-38 per cent) (2019).

Gender blindness causes problems for sustainable resource management. For example, women's fishing often includes gleaning in the intertidal zone, which is rarely included in fisheries monitoring, meaning that monitoring is failing to pick up important information about human effects on marine ecosystems (Kleiber et al., 2015). Fijian women mud crab fishers have taken matters into their own hands and established a community-based fisheries management plan to address overfishing (Giffin et al., 2019). Vanuatu fisheries managers (pers. comm. with Barclay, May 2017) related that recent efforts to be more inclusive in their community consultations have revealed new and important factors for coastal fisheries management. In the past they had not been aware of practices used in octopus fishing, because it is mainly women who fish for octopus in shallow waters. Fisheries managers had been used to talking only to men about fishing and focused on the types of fishing men did, usually further out from shore using boats. In the 2010s they started talking with women about their fishing. They discovered that the main way women fished for octopus was through using metal bars to break or overturn the corals octopuses hide in, which is a destructive fishing practice. If they had only talked to men, as in the past, they would have remained unaware that destructive fishing practices were being used to fish for octopus, and, thus, not addressed the problem.

In a community in Solomon Islands, research around fishing practices found that a local MPA was less effective than it could have been due to gender blindness in creating the MPA. Women were not effectively consulted and the MPA was placed over fishing grounds women commonly used. Thus, the MPA establishment process lacked legitimacy in women's eyes, and obeying the rules of the MPA would have made their lives more 
difficult due to having to go further afield to fish, so some women were flouting the rules of the MPA by fishing in the no-take zone (Rohe et al., 2018).

Another example of overlooking the resource sustainability implications of near-shore fishing for invertebrates as part of a livelihood activity mainly conducted by women is that of shell money in the Langalanga Lagoon in Solomon Islands (see Fig. 3.2). Various kinds of customary exchange valuables have long been part of cultural life in Melanesia. The shell money produced in the Langalanga Lagoon continues to be valued

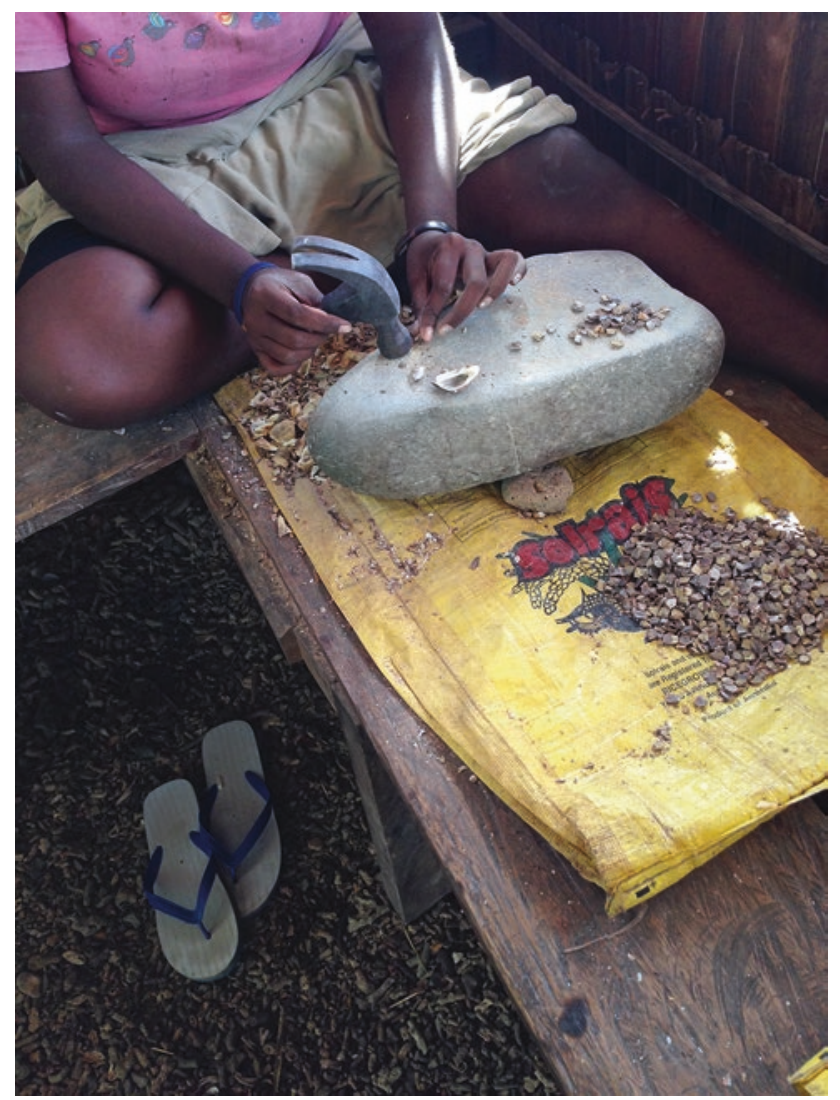

Fig. 3.2 Shell money production in Langlalanga Lagoon, Solomon Islands. (Photo credit: Kate Barclay) 
in modern life, with some types of pieces being used for weddings and other ceremonial purposes, and simpler pieces used as casual jewellery. White beads are made from a shell called in local language kakadu (Anadara granosa) and black beads used at the end of shell money strings are from kurila (Atrina vexillum). Some beads are heated to bring out their colour, including red beads from romu (Chama pacifica) and orange beads ke'e (Beguina semiorbiculata). With continuing demand for shell money the shells used have been depleted in the Langalanga area, so are supplied from further afield in Solomon Islands. By 2014 traders were reporting that overfishing might also be occurring outside Langalanga, because the size of shells was getting smaller (Barclay et al., 2018). Solomon Islands has some important export fisheries for invertebrates, such as sea cucumber, trochus and pearl shells, so has long been monitoring and attempting to tackle overfishing through periodic export bans. However, the shells used for shell money are not on the list of species for monitoring. We do not know why this is the case, but in line with the global tendency to overlook women in fisheries, we speculate that it could be because shell money production in Langalanga is largely women's activity.

Another problem that arises from the invisibility of women's fishing is that training or funding for fisheries-related livelihood activities is usually targeted at men. For example, a project to support community-based aquaculture in Pacific Island countries included a specific gender focus and engaged gender specialists in some of their activities (Jimmy et al., 2019). They found in Fiji and Samoa that women and men tended to identify men as the fish farmers, and not women, despite the fact that women were doing much of the day-to-day work operating fish farms. A handful of farms in Fiji run by women were exceptions to this rule. In the past the tendency to assume men were fish farmers and women were not meant that men received any training and were the ones involved in discussions with the fisheries agency supporting aquaculture, where decisions were made. The project concluded that fisheries agencies should have capacity building for gender analysis and gender mainstreaming so that they would be better able to observe where women were involved and include them appropriately in interventions (Jimmy et al., 2019). These findings are similar to case studies of aquaculture in Bangladesh, where women's involvement is also underestimated, showing that with careful project design women may be empowered (Choudhury et al., 2017). 
Even when fisheries agencies and other organisations involved in funding or implementing fisheries livelihood projects recognise that women are important players and should be involved, ingrained gender roles, norms and expectations can make it difficult to meaningfully engage women. It is not as simple as just inviting women to the meetings where projects will be planned and decisions made-although that is a necessary first small step. After the WorldFish office in Solomon Islands had been through a process of capacity building to tackle gender transformation in their work, they started to implement this in their work with fishing communities. In one of their early attempts they found difficulties even in inviting women to meetings when they went out to villages. Their established way of inviting people to meetings was by letter or through other communication with village leaders, who were men and who were not accustomed to passing on news about such upcoming meetings to women in their communities. Thus, the fieldworkers had to organise meetings with women once they arrived, by walking around the village and seeing which women could participate at short notice. For their part women were not accustomed to participating in such meetings, so eliciting their participation was hard, and focus groups took much longer than planned. Women in Solomon Islands have less formal schooling than men, so it was more difficult to translate some concepts that were not part of their daily lives, such as 'nutrition' (Jones et al., 2014). Pursuing their aim for livelihoods activities to be gender transformative, over the years since that first attempt WorldFish Solomon Islands staff have accumulated learning about how to effectively engage village women in livelihood activities. These include many practical points such as ensuring that women are not spending a great deal of time cooking for visitor meetings, and that meetings work around any caring responsibilities women may have (Gomese et al., 2020; Lawless et al., 2017).

Finally, gender intersects with other forms of social marginalisation. Some communities, including the women in them, see that the most pressing social issues affecting their livelihoods are related to factors other than gender, and they want those other issues dealt with first in any interventions. For example, in a study of the contributions of tuna fisheries to coastal communities, one of the study areas was a fishing village specialising in handlining for yellowfin tuna near Gizo in Solomon Islands. The members of this village are ethnic I-Kiribati, having migrated from the former British territory of the Gilbert and Ellis Islands during the twentieth century, but they are Solomon Islands citizens (McClean et al., 2019). 
The broader study found that across the study locations in Solomon Islands and Indonesia the main factors affecting the distribution of contributions from fisheries to livelihoods were gender, ethnicity (especially migrant status) and socio-economic status. However, when the Gizo participants (women and men) were asked about gender as a factor, they responded that they were not concerned about the gender relations in fishing. They wanted the project to report on their marginalisation as a migrant community, and for any interventions to address those problems (McClean et al., 2019).

\section{CONCLUSION}

While the idea of a 'fisher' is a convenient shorthand term, it conceals both the diversity of practices associated with a fishing livelihood, and the other forms of identity that interact with a fishing livelihood. Different types of fishers and others whose livelihoods are based on the fish value chain have different sets of interests, and frequently these roles correspond with other forms of identity such as gender or ethnicity. Such forms of difference are also organised hierarchically in relations of power (i.e., particular groups of fishers and social groups tend to be marginalised, while others are not). While in some contexts such forms of marginalisation are arguably becoming increasingly well recognised (e.g., in relation to gender), in other contexts marginalisation can be more difficult to unpack and recognise (e.g., relationships between recent migrants and long-term residents).

The implication for fisheries governance is that these forms of social differentiation influence how people respond to or are affected by any new fisheries governance initiative. For example, a new MPA or the imposition of a closed season is mediated and influenced by these social institutions. Failure to be inclusive can simply mean that the governance intervention fails to achieve its objectives, as in the case of the MPA in Solomon Islands (Rohe et al., 2018), while inclusive resource management can enable fisheries agencies to better manage resources, as in the case of octopus fishing in Vanuatu. In some cases, failure to be inclusive can lead to significant social effects and generate social tensions (e.g., Segi, 2014b). While the challenges for organisations and policymakers in recognising and addressing social difference are significant, and require long-term sustained effort, the potential for genuinely improving fishing livelihoods is correspondingly substantial. For example, WorldFish as an organisation has spent many years embedding a gender transformative approach to its work. It 
can now point to measurable outcomes from interventions, whereby women have increased choice regarding income activities in seafood supply chain and control over the income they generate, with corresponding positive effects for their families (Cole et al., 2020).

\section{REFERENCES}

Barclay, K., McClean, N., Foale, S., Sulu, R., \& Lawless, S. (2018). Lagoon livelihoods: Gender and shell money in Langalanga, Solomon Islands. Maritime Studies, 17, 199-211. https://doi.org/10.1007/s40152-018-0111-y

Barclay, K., Leduc, B., Mangubhai, S., Vunisea, A., Namakin, B., Teimarane, M., \& Leweniqila, L. (2019). Module 1: Introduction. In K. Barclay, B. Leduc, S. Mangubhai, \& C. Donato-Hunt (Eds.), Pacific handbook for gender equity and social inclusion in coastal fisheries and aquaculture. Pacific Community (SPC).

Béné, C. (2003). When fishery rhymes with poverty: A first step beyond the old paradigm on poverty in small-scale fisheries. World Development, 31(6), 949-975. https://doi.org/10.1016/S0305-750X(03)00045-7

Béné, C., \& Friend, R. M. (2011). Poverty in small-scale fisheries: Old issue, new analysis. Progress in Development Studies, 11(2), 119-144. https://doi. org/10.1177/146499341001100203

Bernstein, H. (2010). Class dynamics of agrarian change (Vol. 1). Kumarian Press.

Choudhury, A., McDougall, C., Rajaratnam, S., \& Park, C. M. Y. (2017). Women's empowerment in aquaculture: Two case studies from Bangladesh. FAO; WorldFish.

Cole, S. M., Kaminski, A. M., McDougall, C., Kefi, A. S., Marinda, P. A., Maliko, M., \& Mtonga, J. (2020). Gender accommodative versus transformative approaches: A comparative assessment within a post-harvest fish loss reduction intervention. Gender, Technology and Development, 24(1), 48-65. https://doi. org/10.1080/09718524.2020.1729480

Coulthard, S. (2008). Adapting to environmental change in artisanal fisheriesInsights from a South Indian Lagoon. Global Environmental Change, 18(3), 479-489. https://doi.org/10.1016/j.gloenvcha.2008.04.003

De Haan, L., \& Zoomers, A. (2005). Exploring the frontier of livelihoods research. Development and Change, 36(1), 27-47. https://doi.org/10.1111/j.0012155X.2005.00401.x

Dressler, W. H., \& Fabinyi, M. (2011). Farmer gone fish'n? Swidden decline and the rise of grouper fishing on Palawan Island, the Philippines. Journal of Agrarian Change, 11(4), 536-555. https://doi.org/10.1111/j.1471-0366. 2011.00309.x

Dressler, W. H., \& Turner, S. (2008). The persistence of social differentiation in the Philippine uplands. The Journal of Development Studies, 44(10), 1450-1473. https://doi.org/10.1080/00220380802360966 
Eder, J. F. (2005). Coastal resource management and social differences in Philippine fishing communities. Human Ecology, 33(2), 147-169. https://doi. org/10.1007/s10745-005-2430-Z

Eder, J. F. (2008). Migrants to the coasts: Livelihood, resource management, and global change in the Philippines. Nelson Education.

Fabinyi, M. (2012). Fishing for fairness. ANU Press.

Fabinyi, M., Foale, S., \& Macintyre, M. (2015). Managing inequality or managing stocks? An ethnographic perspective on the governance of small-scale fisheries. Fish and Fisheries, 16(3), 471-485. https://doi.org/10.1111/faf.12069

Fabinyi, M., Dressler, W. H., \& Pido, M. D. (2017). Fish, trade and food security: Moving beyond 'availability' discourse in marine conservation. Human Ecology, 45(2), 177-188. https://doi.org/10.1007/s10745-016-9874-1

Galvez, R. E., Hingco, T.G., Bautista, C., \& Tungpalan, M. T. (1989). Sociocultural dynamics of blast fishing and sodium cyanide fishing in two fishing villages in the Lingayen Gulf area. In G. Silvestre, E. Miclat, \& C. Thia-Eng (Eds.), Towards sustainable development of the coastal resources of Lingayen Gulf, Philippines (pp. 43-62). ICLARM Conference Proceedings 17. International Center for Living Aquatic Resources Management.

Geertz, C. (1973). The interpretation of cultures. Basic Books.

Giffin, A. L., Naleba, M., Fox, M., \& Mangubhai, S. (2019). Women fishers in Fiji launch a mud crab management plan for their fishery. SPC Women in Fisheries Information Bulletin, 30, 20-23.

Gomese, C., Siota, F., Ride, A., \& Kleiber, D. (2020). Reflections on integrating gender-sensitive facilitation techniques in fieldtrip reports. SPC Women in Fisheries Information Bulletin, 32, 28-30.

Gopal, N., Hapke, H. M., Kusakabe, K., Rajaratnam, S., \& Williams, M. J. (2020). Expanding the horizons for women in fisheries and aquaculture. Gender, Technology and Development, 24(1), 1-9. https://doi.org/10.1080/0971852 4.2020.1736353

Hall, D., Hirsch, P., \& Li, T. M. (2011). Powers of exclusion: Land dilemmas in Southeast Asia. University of Hawai'i Press.

Harper, S., Zeller, D., Hauzer, M., Pauly, D., \& Sumaila, U. R. (2013). Women and fisheries: Contribution to food security and local economies. Marine Policy, 39(1), 56-63. https://doi.org/10.1016/j.marpol.2012.10.018

Harper, S., Adshade, M., Lam, V. W. Y., Pauly, D., \& Sumaila, U. R. (2020). Valuing invisible catches: Estimating the global contribution by women to small-scale marine capture fisheries production. PLoS One, 15(3), 1-17. https://doi.org/10.1371/journal.pone.0228912

Hornborg, A., Clark, B., \& Hermele, K. (Eds.). (2013). Ecology and power: Struggles over land and material resources in the past, present and future (Vol. 18). Routledge.

Jimmy, R., Pickering, T., \& Tioti, B. (2019). Improving community-based aquaculture in Fiji, Kiribati, Samoa and Vanuatu. Final Report, FIS/2012/076. ACIAR. 
Jones, C., Schwarz, A. M., Sulu, R., \& Tikai, P. (2014). Foods and diets of communities involved in inland aquaculture in Malaita Province, Solomon Islands. Program Report, AAS-2014-30. CGIAR Research Program on Aquatic Agricultural Systems.

Kerkvliet, B. J. T. (1990). Everyday politics in the Philippines: Class and status relations in a Central Luzon village. University of California Press.

Kleiber, D., Harris, L. M., \& Vincent, A. C. J. (2015). Gender and small-scale fisheries: A case for counting women and beyond. Fish and Fisheries, 16(4), 547-562. https://doi.org/10.1111/faf.12075

Knudsen, M. (2012). Fishing families and cosmopolitans in conflict over land on a Philippine island. Journal of Southeast Asian Studies, 43(3), 478-499. https:// doi.org/10.1017/S0022463412000355

Knudsen, M. (2013). Beyond clientelism: Neighbourhood leaders on a Philippine Island. Anthropological Forum, 23(3), 242-265. https://doi.org/10.108 0/00664677.2013.812032

Knudsen, M. (2016). Poverty and beyond: Small-scale fishing in overexploited marine environments. Human Ecology, 44(3), 341-352. https://doi. org/10.1007/s10745-016-9824-y

Lawless, S., Doyle, K., Cohen, P., Eriksson, H., Schwarz, A. -M., Teioli, H., McDougall, C., et al. (2017). Considering gender: Practical guidance for rural development initiatives in Solomon Islands. Program Brief 2017-22. WorldFish.

Li, T. M. (2000). Articulating Indigenous identity in Indonesia: Resource politics and the tribal slot. Comparative Studies in Society and History, 42(1), 149-179. https://doi.org/10.1017/S0010417500002632

Lowe, C. (2002). Who is to blame? Logics of responsibility in the live reef food fish trade in Sulawesi, Indonesia. SPC Live Reef Fish Information Bulletin, 10, 7-16.

McCall Howard, P. (2012). Sharing or appropriation? Share systems, class and commodity relations in Scottish fisheries. Journal of Agrarian Change, 12(2-3), 316-343. https://doi.org/10.1111/j.1471-0366.2011.00355.x

McClean, N., Barclay, K., Fabinyi, M., Adhuri, D. S., Sulu, R. J., \& Indrabudi, T. (2019). Assessing tuna fisheries governance for community wellbeing: Case studies from Indonesia and Solomon Islands. University of Technology Sydney. Retrieved February 5, 2021, from https://www.uts.edu.au/about/facultyarts-and-social-sciences/research/fass-research-projects/assessinggovernance-tuna

Mills, D., Béné, C., Ovie, S., Tafida, A., Sinaba, F., Kodio, A., Lemoalle, J., et al. (2011). Vulnerability in African small-scale fishing communities. Journal of International Development, 23(2), 308-313. https://doi.org/10.1002/ jid. 1638

Padilla, J. E., Mamauag, S., Braganza, G., Brucal, N., Yu, D., \& Morales, A. (2003). Sustainability assessment of the live reef-fish for food industry in Palawan, Philippines. Philippines: World Wildlife Fund. 
Pauwelussen, A. P. (2015). The moves of a Bajau middlewoman: Understanding the disparity between trade networks and marine conservation. Anthropological Forum, 25(4), 329-349. https://doi.org/10.1080/00664677.2015.1054343

Peet, R., \& Watts, M. (Eds.). (1996). Liberation ecologies: Environment, development, social movements. Routledge.

Rabbitt, S., Lilley, I., Albert, S., \& Tibbetts, I. R. (2019). What's the catch in who fishes? Fisherwomen's contributions to fisheries and food security in Marovo Lagoon, Solomon Islands. Marine Policy, 108, 103667. https://doi. org/10.1016/j.marpol.2019.103667

Ram, K. (1991). Mukkuvar women: Gender, hegemony, and capitalist transformation in a south Indian fishing community. Zed Books.

Ribot, J. C., \& Peluso, N. L. (2003). A theory of access. Rural Sociology, 68(2), 153-181. https://doi.org/10.1111/j.1549-0831.2003.tb00133.x

Rocheleau, D., Thomas-Slayter, B., \& Wangari, E. (Eds.). (1996). Feminist political ecology: Global issues and local experience. Routledge.

Rohe, J., Schlüter, A., \& Ferse, S. C. A. (2018). A gender lens on women's harvesting activities and interactions with local marine governance in a South Pacific fishing community. Maritime Studies, 17, 155-162. https://doi. org/10.1007/s40152-018-0106-8

Ruddle, K. (2011). 'Informal' credit systems in fishing communities: Issues and examples from Vietnam. Human Organization, 70(3), 224-232. https://doi. org/10.17730/humo.70.3.v4810k37717h9g01

Russell, S. D. (1987). Middlemen and moneylending: Relations of exchange in a highland Philippine economy. Journal of Anthropological Research, 43(2), 139-161.

Russell, S., \& Poopetch, M. (1990). Petty commodity fishermen in the inner gulf of Thailand. Human Organization, 49(2), 174-187. https://doi. org/10.17730/humo.49.2.u26301427q364380

Sahlins, M. (1978). Culture as protein and profit. New York Review of Books, $25(18), 45-53$.

Scoones, I. (2009). Livelihoods perspectives and rural development. The Journal of Peasant Studies, 36(1), 171-196. https://doi.org/10.1080/03066 150902820503

Secretariat of the Pacific Community. (2017). Coastal fishery report card 2017. Pacific Community (SPC). Retrieved February 5, 2021, from http://www.spc. int/DigitalLibrary/Doc/FAME/Brochures/SPC_2016_Coastal_Fishery_ Report_Card.pdf

Secretariat of the Pacific Community. (2018). Coastal fishery report card 2018. Pacific Community (SPC). Retrieved February 5, 2021, from http://www.spc. int/DigitalLibrary/Doc/FAME/Brochures/SPC_2018_Coastal_Fishery_ Report_Card.pdf

Secretariat of the Pacific Community. (2019). Coastal fishery report card 2019. Pacific Community (SPC). Retrieved February 5, 2021, from http://www.spc. int/DigitalLibrary/Doc/FAME/Brochures/SPC_2019_Coastal_Fishery_ Report_Card.pdf 
Segi, S. (2014a). 'Losing at sea, winning on land': A case study of Philippine smallscale and industrial fisher resource competition. Society \& Natural Resources, 27(12), 1227-1241. https://doi.org/10.1080/08941920.2014.948237

Segi, S. (2014b). Protecting or pilfering? Neoliberal conservationist marine protected areas in the experience of coastal Granada, the Philippines. Human Ecology, 42(4), 565-575. https://doi.org/10.1007/s10745-014-9669-1

Sidel, J. T. (1999). Capital, coercion, and crime: Bossism in the Philippines. Stanford University Press.

Stacey, N., Steenbergen, D. J., Clifton, J., \& Acciaioli, G. L. (2018). Understanding social wellbeing and values of small-scale fisheries amongst the Sama-Bajau of archipelagic Southeast Asia. In D. S. Johnson, T. G. Acott, N. Stacey, \& J. Urquhart (Eds.), Social wellbeing and the values of small-scale fisheries (pp. 97-123). Springer.

Szanton, M. C. B. (1972). A right to survive: Subsistence marketing in a lowland Philippine town. Pennsylvania State University Press.

Thomas, A. S., Mangubhai, S., Fox, M., Lalavanua, W., Meo, S., Miller, K., Naisilisili, W., et al. (2020). Valuing the critical roles and contributions of women fishers to food security and livelihoods in Fiji. Women in Fisheries Information Bulletin, 31, 22-29.

Turgo, N. (2016). 'Laway lang ang kapital' (Saliva as capital): Social embeddedness of market practices in brokerage houses in the Philippines. Journal of Rural Studies, 43, 83-93. https://doi.org/10.1016/j.jrurstud.2015.11.001

Weeratunge, N., Snyder, K. A., \& Sze, C. P. (2010). Gleaner, fisher, trader, processor: Understanding gendered employment in fisheries and aquaculture. Fish and Fisheries, 11(4), 405-420. https://doi.org/10.1111/j.14672979.2010.00368.x

Open Access This chapter is licensed under the terms of the Creative Commons Attribution 4.0 International License (http://creativecommons.org/licenses/ by $/ 4.0 /$ ), which permits use, sharing, adaptation, distribution and reproduction in any medium or format, as long as you give appropriate credit to the original author(s) and the source, provide a link to the Creative Commons licence and indicate if changes were made.

The images or other third party material in this chapter are included in the chapter's Creative Commons licence, unless indicated otherwise in a credit line to the material. If material is not included in the chapter's Creative Commons licence and your intended use is not permitted by statutory regulation or exceeds the permitted use, you will need to obtain permission directly from the copyright holder.

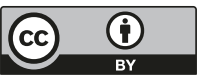

